Teknik, 37 (1), 2016, 41-46

\title{
Perbandingan Karakteristik Lempung Kasongan dan Godean Sebagai Bahan Baku Industri Gerabah Kasongan
}

\author{
Tri Winarno* \\ Program Studi Teknik Geologi, Fakultas Teknik Universitas Diponegoro, \\ Jl. Prof. Soedarto, SH, Kampus Undip Tembalang, Semarang, Indonesia 50275
}

\begin{abstract}
ABSTRAK
Kasongan adalah salah satu sentra industri keramik dan gerabah di Yogyakarta yang terletak di Desa Bangunjiwo, Kecamatan Kasihan, Kabupaten Bantul. Pada saat ini industri keramik dan gerabah Kasongan mengalami kesulitan bahan baku lempung dikarenakan cadangan lempung di Desa Bangunjiwo yang selama ini digunakan semakin berkurang jumlahnya. Berdasarkan studi pustaka diketahui bahwa di Godean terdapat cadangan lempung, sehingga perlu diteliti apakah bisa digunakan sebagai bahan baku dalam industri keramik dan gerabah. Metode yang digunakan untuk menguji karakteristik lempung tersebut adalah dengan analisis XRD, XRF, analisis tingkat kecerahan, analisis ukuran butir dan pengujian pembuatan gerabah dari lempung tersebut. Hasil penelitian menunjukkan mineral lempung penyusun lempung Bangunjiwo adalah kaolinit dan haloisit, sedangkan di Godean terususun atas kaolinit, haloisit dan smektit. Dalam pengujian pembuatan gerabah dengan lempung dari kedua daerah tersebut menunjukkan perbedaan hasil, dimana lempung dari Godean menghasilkan gerabah yang tidak menyerupai ciri khas gerabah Kasongan yang berwarna merah terang. Dengan demikian lempung dari Godean tidak bisa digunakan sebagai pengganti bahan baku industri gerabah Kasongan.
\end{abstract}

Kata kunci: Kasongan; Godean; karakteristik lempung; gerabah

\begin{abstract}
[Title: The Characteristic Comparison of Kasongan Clay and Godean Clay as Raw Material in Kasongan pottery Industry] Kasongan is the center of ceramics and pottery industry in Yogyakarta,located in Bangunjiwo village, Kasihan District, Bantul Regency. Nowadays, the ceramics and pottery industry is difficult to find the raw material because of the decrease of the Bangunjiwo clay deposit. Based on literature review, there are clay deposits found in Godean which can be observed their characteristics as basic commodity in the ceramics and pottery industry. The methods apllied in this research are XRD and XRF analysis,brightness analysis, grain size analysis and making pottery from those clays. The result of the research shows that the clay in Bangunjiwo consists of kaolinite and halloysite, while clay in Godean consists of kaolinite, halloysite and smectite. The pottery products made from those clays show different characteristics. The clay from Godean does not show bright red colour as the Kasongan clay. So the clay from Godean can not be used as the alternative raw material for the Kasongan pottery industry.
\end{abstract}

Keywords: Kasongan; Godean; clay characteristic; pottery

\section{Pendahuluan}

Kasongan adalah nama daerah tujuan wisata di wilayah Kabupaten Bantul, Daerah Istimewa Yogyakarta yang terkenal dengan hasil kerajinan gerabahnya. Daerah ini terletak di Pedukuhan Kajen, Desa Bangunjiwo, Kecamatan Kasihan, Kabupaten Bantul, Propinsi Daerah Istimewa Yogyakarta, sekitar $6 \mathrm{~km}$ dari Alun-alun Utara Yogyakarta ke

\footnotetext{
${ }^{*}$ Penulis Korespondensi.

E-mail: triwingeo@gmail.com
}

arah Selatan (Gambar 1).

Bahan baku utama yang digunakan oleh pengrajin gerabah di Kasongan adalah lempung yang berasal dari Desa Bangunjiwo, yang terletak berdekatan dengan sentra industri gerabah Kasongan. Lempung dari Bangunjiwo tersebut kemudian dicampur dengan lempung dari daerah lain dan pasir untuk dijadikan adonan bahan gerabah (Perdana dkk, 2012). Seiring waktu, persediaan lempung Bangunjiwo semakin terbatas dan kualitasnya semakin menurun (Perdana dkk, 2012). Akibatnya para pengrajin kesulitan untuk mencari bahan baku 
lempung untuk menjaga keberlangsungan industri keramik yang telah berlangsung turun-temurun tersebut.

Berdasarkan studi literatur, diketahui bahwa di daerah Godean, Kabupaten Sleman, terdapat endapan lempung sehingga dapat dilakukan penelitian apakah lempung pada daerah tersebut dapat digunakan sebagai bahan baku industri gerabah Kasongan, menggantikan lempung Bangunjiwo.

Tujuan penelitian ini adalah menentukan karakteristik lempung yang dipersyaratkan dalam industri gerabah, baik karakteristik fisik, kimia dan mineralogi di lokasi penelitian, yaitu lempung di daerah Kasongan dan Godean.

\section{Konsep Teori}

Pengertian keramik dalam Dictionary of Art (Mills, 1965 dalam Pandanwangi, 2011) menyebutkan bahwa kata keramik berasal dari bahasa Yunani yaitu kata "keramikos" yang berarti bendabenda yang terbuat dari tanah liat; yang merupakan suatu istilah umum untuk studi seni dari pottery dalam arti kata yang luas, termasuk segala macam bentuk benda yang terbuat dari tanah liat dan dibakar serta mengeras oleh api. Sedangkan menurut Balai Besar Keramik Bandung (dalam Pandanwangi, 2011) keramik adalah produk yang terbuat dari bahan galian anorganik non-logam yang telah mengalami proses panas yang tinggi dan bahan jadinya mempunyai struktur kristalin dan non-kristalin atau campuran dari keduanya.

Gerabah adalah peralatan yang terbuat dari tanah liat yang dibentuk dengan cara beberapa teknik kemudian dibakar dan produknya dipergunakan untuk peralatan yang menunjang kehidupan sehari hari, seperti gentong tempat air, kendi, dan lain-lain. Permukaan gerabah pada umumnya tidak diglasir, berwarna merah atau hitam sesuai dengan warna asli tanah liat yang terkena pembakaran. Istilah 'gerabah' juga dikenal dengan keramik tradisional sebagai hasil dari kegiatan kerajinan masyarakat pedesaan dari tanah liat, ditekuni secara turun temurun. Gerabah juga disebut keramik rakyat, karena mempunyai ciri pemakaian tanah liat bakaran rendah dan teknik pembakaran sederhana (Oka, 1979 dalam Pandanwangi, 2011).

Pada dasarnya bahan dasar keramik antara lain (Rhodes, 1969):

1. Mineral lempung

Industri keramik dan gerabah adalah pengguna terbesar mineral lempung, yaitu sekitar $70 \%$. Lempung memiliki sifat-sifat yang khas yaitu bila dalam keadaan basah mempunyai sifat plastis tetapi bila dalam keadaan kering akan menjadi keras, sedangkan bila dibakar akan menjadi padat dan kuat.

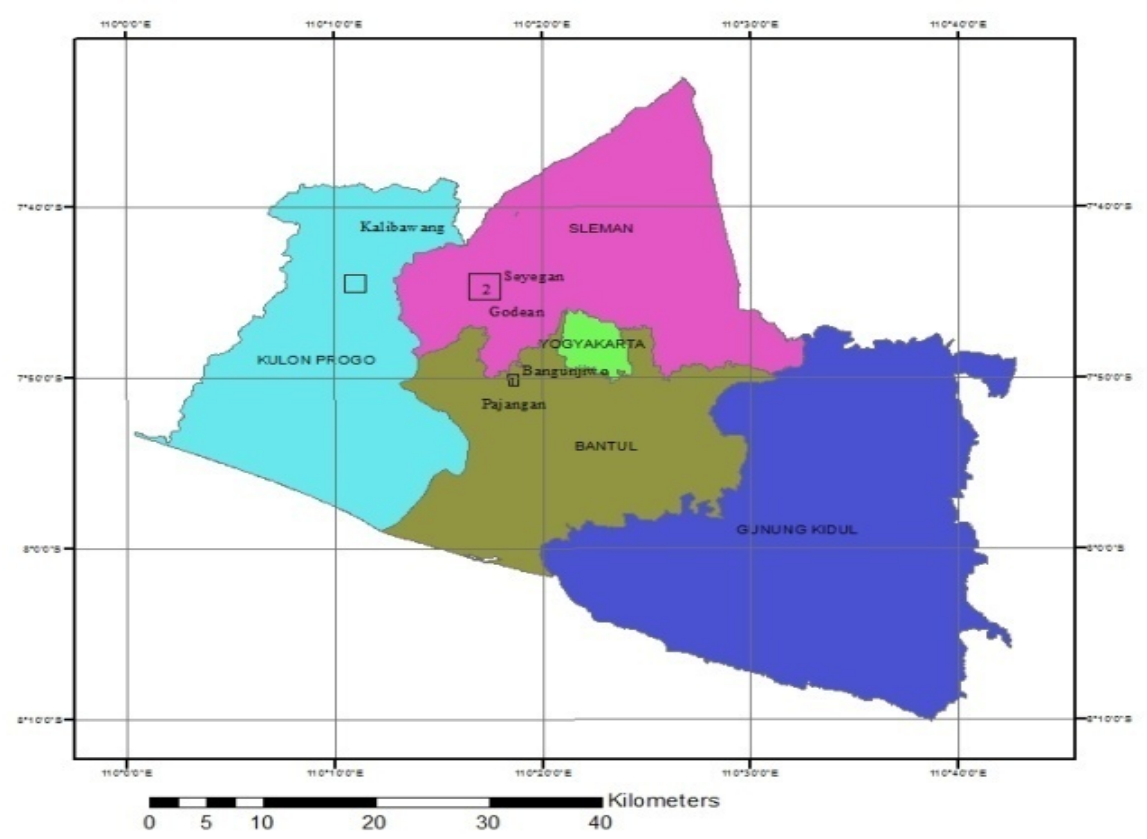

PETA LOKASI PENELITIAN

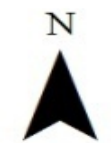

1 Lokasi Penelitian B angunjiwo

Lokasi Penelitian Godean \& Seyegan

Gambar 1. Lokasi penelitian berada di Desa Bangunjiwo, Kasihan, Bantul dan Godean Kabupaten Sleman, Provinsi Daerah Istimewa Yogyakarta. 
Jenis mineral lempung yang sering dijadikan bahan baku dalam industri keramik adalah kaolin. Sifat-sifat mineral kaolin antara lain, yaitu: kekerasan 2 - 2,5, berat jenis 2,6 - 2,63, plastis, mempunyai daya hantar panas dan listrik yang rendah, serta $\mathrm{pH}$ bervariasi.

\section{Kuarsa $\left(\mathrm{SiO}_{2}\right)$}

Kuarsa (mineral silika) adalah salah satu komponen utama dalam pembentukan keramik dan banyak terdapat di permukaan bumi (sekitar 60\%). Kuarsa memiliki keplastisan rendah dan titik lebur tinggi sekitar $1728^{\circ} \mathrm{C}$, tetapi hasil pembakarannya kuat dan keras. Bahan baku kuarsa dapat diperoleh dari batuan atau pasir kuarsa dengan kandungan silika tinggi.

\section{Feldspar}

Feldspar adalah suatu kelompok mineral merupakan penyusun batuan beku yang dapat memberikan sampai 25\% flux (pelebur) pada badan keramik. Bila keramik dibakar, feldspar akan meleleh (melebur) dan membentuk leburan gelas yang menyebabkan partikel tanah dan bahan lainnya melekat satu sama lain. Pada saat membeku, bahan ini memberikan kekuatan pada badan keramik. Feldspar tidak larut dalam air, mengandung alumina, silika dan flux yang digunakan untuk membuat gelasir suhu tinggi.

\section{Serbuk Kaca/Cullet}

Cullet adalah serbuk kaca yang sangat kecil. Kaca biasanya dihasilkan dari campuran silika atau bahan dioksida $\left(\mathrm{SiO}_{2}\right)$ yang merupakan benda amorf, dibentuk melalui proses pemadatan dari peleburan tanpa kristalisasi.

\section{Metode Penelitian}

Sampel yang diperoleh dari lapangan kemudian dianalisis di laboratorium, yang meliputi analisis XRD, XRF, tingkat kecerahan, ukuran butir dan ujicoba pembuatan gerabah.

\subsection{Analisis Mineralogi}

Analisis mineralogi dilakukan dengan analisis XRD (X-Ray Diffraction Analysis) untuk mengamati struktur kristal mineral, termasuk susunan atom, ukuran kristal dan pengotornya. Analisis XRD dapat digunakan untuk mengkarakterisasi suatu lempung dan mengidentifikasi jenis lempung yang ada dalam suatu sampel.

\subsection{Analisis Kimia}

Analisis kimia dilakukan dengan analisis $\mathrm{XRF}$, untuk menganalisis elemen-elemen utama dan unsur-unsur jejak beserta konsentrasinya pada endapan kaolin dengan menggunakan metode spektrometri.

\subsection{Analisis Fisik}

Analisis fisik dilakukan dengan melakukan pengamatan sifat fisik, analisis tingkat kecerahan dan analisis ukuran butir.

\section{Analisis Tingkat Kecerahan}

Analisis tingkat kecerahan dilakukan untuk mengetahui persentasi kecerahan lempung, yang berguna untuk mengetahui kegunaan lempung tersebut dalam industri keramik/gerabah.

\section{Analisis Ukuran Butir}

Analisis besar butir dilakukan untuk mengetahui persentasi ukuran butir yang $<2$ micron. Analisis ini dilakukan dengan menggunakan ayakan. Sampel lempung yang telah disiapkan diayak dengan ayakan berdiameter saringan 2 micron.

\subsection{Uji Coba Pembuatan Gerabah}

Tahap ini dilakukan dengan membuat gerabah dengan menggunakan lempung dari daerah penelitian. kemudian dibentuk dan dibakar. Hasil pengujian ini dipakai untuk melihat apakah lempung dari daerah penelitian dapat digunakan sebagai bahan baku industri gerabah Kasongan.

\section{Hasil dan Pembahasan}

\subsection{Karakteristik Mineralogi}

Untuk mengetahui kandungan mineral lempung dalam sampel lempung dari daerah penelitian, dilakukan dengan analisis XRD.Dari analisis tersebut diperoleh data bahwa kandungan mineral lempung pada tiap daerah penelitian adalah sebagai berikut:

\section{(a). Lempung Kasongan}

Lempung Kasongan yang diuji adalah lempung yang diambil di Desa Bangunjiwo. Hasil pengujian dengan difraksi Sinar-X menunjukkan bahwa mineral lempung penyusun lempung Kasongan adalah haloisit $(\mathrm{d}=10,2727 \AA)$ dan kaolinit (d=7,4433 $\AA$ ).

\section{(b). Lempung Godean}

Lempung dari Godean yang dianalisis adalah lempung yang berasal dari Bukit Jering, Gunung Wungkal dan Gunung Siwareng. Hasil analisis XRD menunjukkan bahwa mineral lempung penyususn 
lempung di Bukit Jering dan Gunung Wungkal adalah smektit dan kaolinit, sedangkan di Gunung Siwareng adalah smektit $(\mathrm{d}=15,8812 \AA)$, kaolinit $(\mathrm{d}=7,3818$ $\AA)$ dan haloisit $(\mathrm{d}=10,8513 \AA)$.

\subsection{Karakteristik Kimia}

Untuk mengetahui karakteristik kimia lempung dari daerah penelitian dilakukan dengan analisis XRF. Analisis tersebut dilakukan untuk mengetahui kadar berbagai oksida di dalam sampel lempung. Lempung Godean yang dianalisis berasal dari Gunung Wungkal.

Ringkasan kandungan oksida lempung dari daerah penelitian dapat dilihat pada Tabel 1.

Tabel 1. Kandungan oksida pada lempung dari daerah penelitian

\begin{tabular}{cccc}
\hline No & Oksida & $\begin{array}{c}\text { Lempung } \\
\text { Kasongan } \\
(\%)\end{array}$ & $\begin{array}{c}\text { Lempung } \\
\text { Godean } \\
(\%)\end{array}$ \\
\hline 1 & $\mathrm{SiO}_{2}$ & 44,17 & 67,2 \\
2 & $\mathrm{Al}_{2} \mathrm{O}_{3}$ & 20,09 & 16,01 \\
3 & $\mathrm{Fe}_{2} \mathrm{O}_{3}$ & 15,76 & 5,25 \\
4 & $\mathrm{TiO}_{2}$ & 1,51 & 0,5 \\
5 & $\mathrm{CaO}$ & 5,69 & 0,75 \\
6 & $\mathrm{MgO}$ & 2,94 & 1,14 \\
7 & $\mathrm{~K}_{2} \mathrm{O}$ & 0,59 & 1,14 \\
8 & $\mathrm{Na}_{2} \mathrm{O}$ & 1,18 & 2,39 \\
9 & $\mathrm{P}_{2} \mathrm{O}_{5}$ & 0,211 & 0,07 \\
10 & $\mathrm{MnO}$ & 0,35 & 0,104 \\
11 & $\mathrm{Cr}_{2} \mathrm{O}_{3}$ & 0,025 & 0,047 \\
12 & $\mathrm{LOI}$ & 7,0 & 5,4 \\
\hline \multicolumn{5}{c}{ Total } & 99,516 & 102,391 \\
\hline
\end{tabular}

\subsection{Karakteristik Fisik}

Karakteristik fisik lempung yang diteliti meliputi kenampakan megaskopis, tingkat kecerahan dan besar butir.

\section{(a). Lempung Kasongan}

Hasil pengamatan fisik terhadap lempung Kasongan menunjukkan warna cokelat kemerahmerahan, menunjukkan rekahan dalam keadaan kering dan lengket dalam keadaan basah (Gambar 2). Di lapangan, sering dijumpai fragmen andesit di dalam kuari lempung tersebut.

Berdasarkan analisis tingkat kecerahan, lempung Kasongan tersebut mempunyai tingkat kecerahan sebesar 20,5\%. Berdasarkan hasil analisis ukuran butir, lempung Kasongan mempunyai partikel berukuran $<400$ Mesh sebesar 74,06\% .

\section{(b). Lempung Godean}

Sebaran lempung di daerah Godean ini mencakup daerah perbukitan yang meliputi Gunung Wungkal, Gunung Siwareng, Gunung Patuk.

Hasil pengamatan fisik terhadap lempung di daerah Godean ini menunjukkan warna warna coklat cerah, bertekstur halus, bersifat lengket dalam keadaan basah dan rapuh dalam keadaan kering (Gambar 3). Hasil analisis tingkat kecerahan terhadap sampel lempung yang diambil di Gunung Wungkal menunjukkan bahwa lempung tersebut mempunyai tingkat kecerahan sebesar 31,2\%. Berdasarkan hasil analisis granulometri, lempung Gunung Wungkal mempunyai partikel yang berukuran $<400$ mesh sebesar $52,30 \%$.

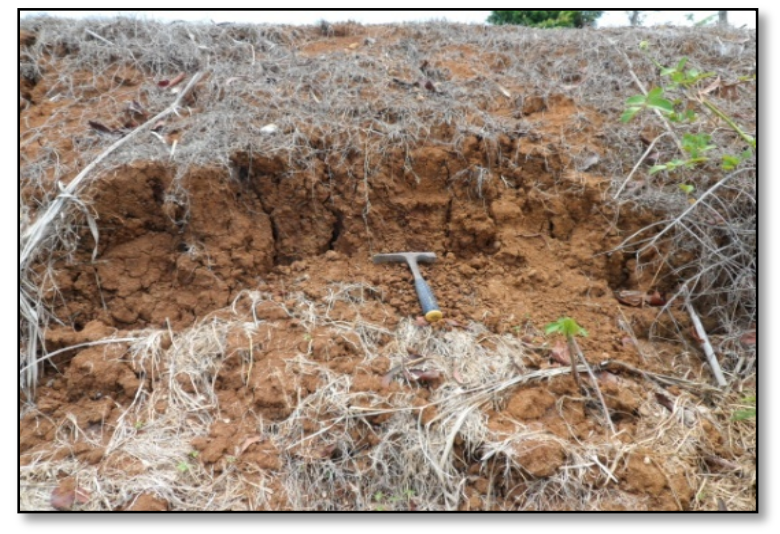

Gambar 2. Kenampakan lempung di Dusun Ngentak, Bangujiwo dalam keadaan kering, yang merupakan bahan baku industri gerabah Kasongan.

\subsection{Karakteristik Hasil Ujicoba dan Pembakaran}

Untuk mengetahui apakah lempung di daerah penelitian bisa digunakan untuk menggantikan lempung Bangunjiwo sebagai bahan baku industri gerabah dan keramik Kasongan, perlu dilakukan ujicoba dengan membuat gerabah dari lempung tersebut dan kemudian membakarnya menjadi produk gerabah.

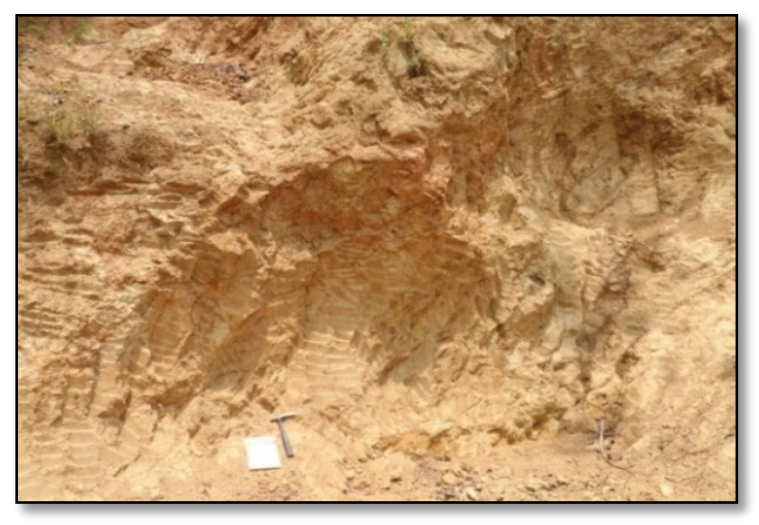

Gambar 3. Kenampakan lempung di Gunung Wungkal, Godean.

Lempung dari daerah penelitian dicampur air dan diolah sampai liat dan bisa dibentuk. Selanjutnya lempung dibentuk menjadi gerabah yang diinginkan. Pembentukan model gerabah tersebut dapat dilakukan dengan cetakan yang terbuat dari 
Teknik, 37 (1), 2016, 44

gipsum maupun dibentuk menggunakan tangan dengan bantuan alat hand wheel atau kick wheel.

Setelah adonan dibentuk menjadi gerabah yang diinginkan, selanjutnya dikeringkan sehingga siap untuk dibakar. Pembakaran dilakukan secara tradisional menggunakan kayu bakar dan jerami dengan suhu sekitar $300^{\circ} \mathrm{C}$.

a. Lempung Kasongan

Lempung tersebut dicampur dengan air untuk dibuat adonan yang siap dibentuk menjadi keramik/gerabah. Adonan tersebut berwarna coklat kehitaman, bertekstur halus, liat dan mudah dibentuk (Gambar 4).

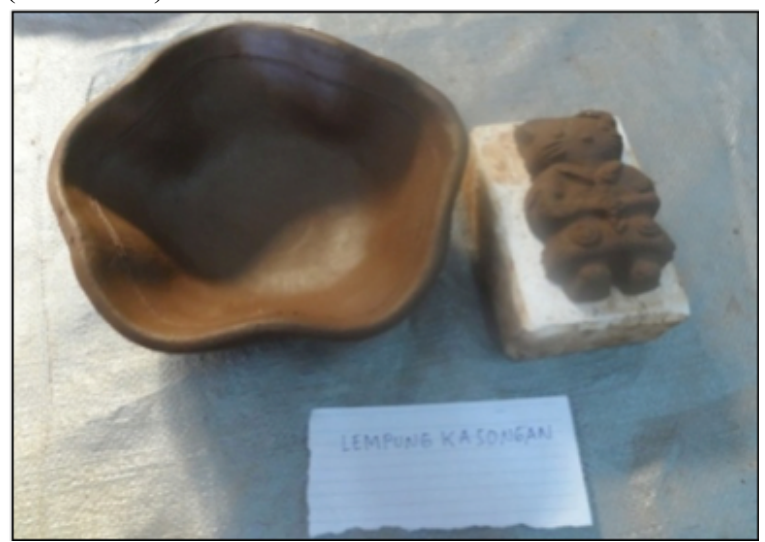

Gambar 4. Gerabah yang dibuat dari lempung Kasongan sebelum dibakar

Hasil pembakaran lempung yang telah dibentuk menjadi gerabah/keramik tersebut menunjukkan warna merah bata, tidak menunjukkan adanya retakan dan pecahan (Gambar 5). Ciri khas gerabah/keramik Kasongan adalah produknya berwarna merah bata.

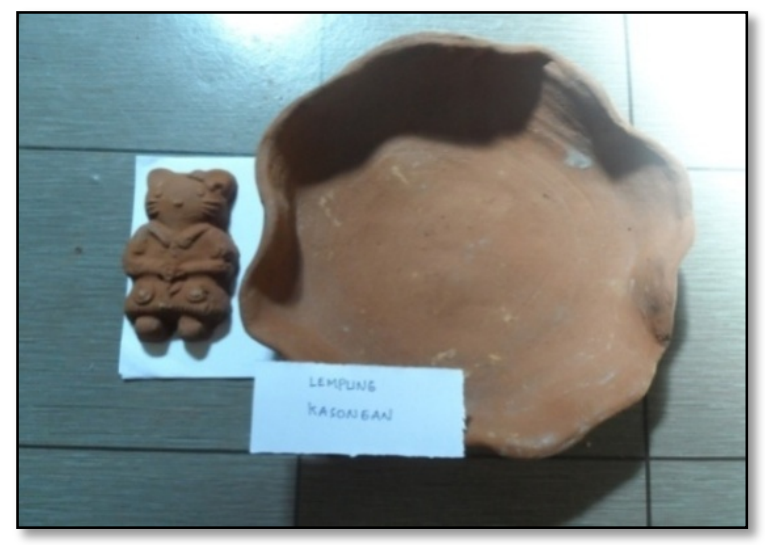

Gambar 5. Gerabah Kasongan setelah dibakar dengan suhu sekitar $300{ }^{\circ} \mathrm{C}$.

\section{b. Lempung Godean}

Lempung dari Bukit Godean yang diujicoba untuk pemnuatan gerabah adalah lempung dari Gunung Wungkal. Adonan lempung Gunung
Wungkal yang telah dicampur air menunjukkan warna coklat, bertekstur halus, masih terdapat partikel berukuran kasar, bersifat kurang liat, mudah patah jika dibentuk dan menunjukkan adanya retakan pada gerabah yang dibentuk (Gambar 6).

Hasil pembakaran lempung Gunung Wungkal yang telah dibentuk menjadi gerabah menunjukkan warna coklat terang, tidak terjadi penambahan retakan setelah dibakar dan tidak mudah patah (Gambar 7).

\subsection{Karakteristik Lempung untuk Bahan Keramik dan Gerabah}

Karakteristik mineral lempung yang diperlukan dalam industri keramik dan gerabah meliputi karakteristik kima dan fisika, seperti yang dipersyaratkan oleh Standar Industri Indonesia, Departemen Perindustrian (1997). Ringkasan karakteristik kimia dan fisika lempung dari tiap lokasi penelitian dapat dilihat pada Tabel 2.

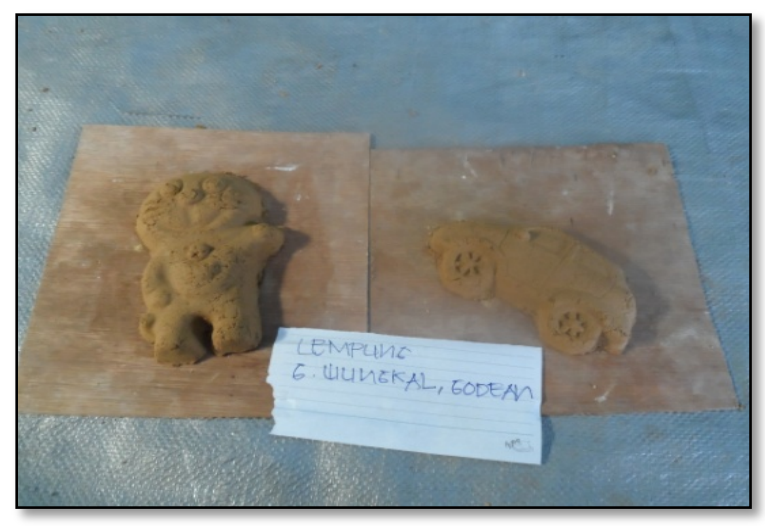

Gambar 6. Gerabah yang dibuat dari lempung Gunung Wungkal, Godeansebelum dibakar

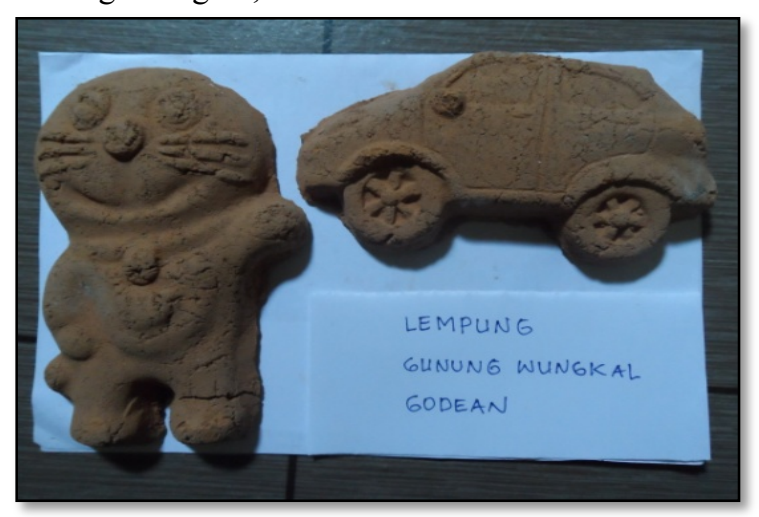

Gambar 7. Gerabah dari Gunung Wungkal, Godean, setelah dibakar dengan suhu sekitar $300{ }^{\circ} \mathrm{C}$.

Selain membandingkan dengan standar dari Departemen Perindustrian, lempung dari daerah peneltian juga dibandingkan dengan karakteristik lempung Bangunjiwo yang merupakan bahan baku industri gerabah dan keramik Kasongan. Hal ini dikarenakan lempung dari daerah penelitian tersebut 
nantinya akan digunakan untuk menggantikan lempung Kasongan sebagai bahan baku industri gerabah dan keramik Kasongan.

Berdasarkan komposisi kimia dan sifat fisika lempung tersebut, maka lempung Kasongan tidak memenuhi persyaratan sebagai bahan untuk membuat keramik (porselen dan saniter) maupun gerabah (gerabah halus maupun kasar), sesuai yang dikeluarkan oleh Departemen Perindustrian (Tabel 2). Akan tetapi berdasarkan hasil uji coba, lempung Kasongan dapat dibentuk menjadi gerabah dan menunjukkan hasil yang bagus. Hasil pembakaran juga menunjukkan bahwa lempung tersebut tidak mengalami pengerutan dan pemecahan selama proses pembakaran.

Kelemahan lempung tersebut adalah dalam hal warna/kecerahan yang kurang cerah, dimana lempung tersebut sebelum dibakar berwarna coklat kehitaman dan setelah dibakar berwarna merah bata. Namun warna merah bata ini menjadi ciri khas gerabah Kasongan yang membedakannya dengan gerabah dari daerah lain.

Dengan kondisi tersebut, maka lempung dari daerah Kasongan tidak cocok untuk digunakan sebagai bahan keramik putih (porselin), tetapi bisa digunakan sebagai bahan gerabah (earthenware). Berdasarkan hasil uji coba, lempung Bukit Godean dapat dibentuk menjadi gerabah, namun menunjukkan adanya retakan pada produk gerabah tersebut sebelum dibakar. Retakan tersebut kemungkinan disebabkan karena adanya kandungan smektit di dalam lempung Gunung Wungkal, dimana smektit mempunyai sifat lebih mudah mengembang jika diberi air dan akan menyusut jika dikeringkan. Selain itu, kandungan ukuran butir kasar yang cukup banyak juga menyebabkan terjadinya retakan tersebut. Akan tetapi, hasil pembakaran menunjukkan bahwa lempung tersebut tidak mengalami pengerutan dan pemecahan lebih lanjut setelah proses pembakaran.

Jika mengacu pada syarat lempung sebagai bahan industri gerabah dan keramik dari Departemen Perindustrian (1997), maka lempung dari Bukit Godean (Gunung Wungkal) hanya memenuhi syarat pada kadar $\mathrm{TiO}_{2}$ dan $\mathrm{CaO}$ (sebagai bahan keramik kelas menengah) dan kadar air (sebagai bahan gerabah halus dan kasar).

Jika dibandingkan dengan lempung Kasongan, maka lempung Gunung Wungkal tersebut mempunyai karakteristik yang jauh berbeda, baik karakteristik fisik, kimia, maupun produk gerabahnya. Lempung Gunung Wungkal mempunyai kadar $\mathrm{Fe}_{2} \mathrm{O}_{3}$ dan ukuran butir yang kurang dari 2 micron yang jauh lebih rendah dibanding lempung Kasongan. Sedangkan produk gerabah yang telah dibakar berwarna coklat terang, dibandingkan lempung Kasongan yang berwarna merah bata.

Dengan kondisi demikian, lempung Gunung Wungkal di Bukit Godean tidak dapat direkomendasikan sebagai bahan pengganti industri gerabah di Kasongan meskipun lempung tersebut dapat digunakan sebagai bahan pembuatan gerabah, namun tidak memiliki ciri khas gerabah Kasongan yang berwarna merah bata.

Tabel 2. Karakteristik kimia dan fisika lempung dari lokasi penelitian dibandingkan dengan Standar Industri Indonesia, Departemen Perindustrian (1997)

\begin{tabular}{|c|c|c|c|c|c|c|}
\hline \multicolumn{7}{|c|}{ Spesifikasi } \\
\hline Analisis & Porselen & Saniter & $\begin{array}{c}\text { Gera } \\
\text { bah } \\
\text { halus }\end{array}$ & $\begin{array}{c}\text { Gera } \\
\text { bah } \\
\text { kasar }\end{array}$ & $\begin{array}{l}\text { Kaso } \\
\text { ngan }\end{array}$ & Godean \\
\hline \multicolumn{7}{|l|}{ Kimia } \\
\hline $\mathrm{Fe}_{2} \mathrm{O}_{3}$ & $<0,4$ & $<0,7$ & $<0,8$ & 1,0 & 15,76 & 5,25 \\
\hline $\mathrm{TiO}_{2}$ & $<0,3$ & $<0,7$ & - & - & 1,51 & 0,5 \\
\hline $\mathrm{CaO}$ & $<0,8$ & $<0,8$ & $<0,8$ & 0,8 & 5,69 & 0,75 \\
\hline $\mathrm{SO}_{3}$ & $<0,3$ & $<0,2$ & $<0,4$ & 0,4 & - & - \\
\hline \multicolumn{7}{|l|}{ Fisika } \\
\hline $\begin{array}{l}\text { Besar butir } \\
<2 \text { micron }\end{array}$ & $>80$ & $>80$ & $>80$ & $>80$ & 74,06 & 52,30 \\
\hline Brightness & $>90$ & $>90$ & $>80$ & $>80$ & 20,5 & 31,2 \\
\hline Kadar air & $<5$ & $<5$ & $<7$ & $<7$ & 7,0 & 5,4 \\
\hline
\end{tabular}


Teknik, 37 (1), 2016, 46

\section{Kesimpulan}

Berdasarkan hasil pengujian, lempung dari daerah Kasongan dan Godean sebenarnya tidak memenuhi persyaratan sebagai bahan baku industri keramik, akan tetapi dapat digunakan sebagai bahan baku industri gerabah. Hasil pembakaran gerabah lempung dari daerah Godean menunjukkan warna cokelat terang, berbeda dengan lempung Kasongan yang berwarna merah bata. Dengan demikian lempung dari daerah Godean tidak dapat direkomendasikan sebagai pengganti bahan baku industri gerabah Kasongan.

\section{Daftar Pustaka}

Chen, P.Y., 1977, Table of Keylines in X-Ray Powder Diffraction Patterns of Minerals in Clays and Associated Rocks, Department of Natural Resources Geological Survey Occasional paper 2, Bloomington, Indiana, USA, 40 hal.

Grim, R.E., 1968, Clay Mineralogy, Second Edition, McGraw-Hill Book Company, New York, USA, 595 hal

Kunrat, T.S., Suhala, S., 1997, Kaolin, dalam Bahan Galian Industri, editor Suhala, S. dan Arifin, M., Pusat Penelitian dan Pengembangan Teknologi Mineral, hal 215-229.

Pandanwangi, A., 2011, Potensi pengembangan Gerabah Bali dan Dampaknya Pada Pemenuhan Kebutuhan Pariwisata di Bali (Studi Kasus Gerabah Desa Adat Kapal, Kecamatan Mengwi, Kabupaten Badung, Bali, Laporan Penelitian, Program Studi Seni Rupa Murni, Fakultas Seni Rupa dan Desain, Universitas Kristen Maranatha, Bandung, 43 hal.

Perdana, I., Harijoko, A. dan Vance Hansen Yong, S., 2012, Karakteristik Bahan dan Termal Lempung Lokal sebagai Bahan Baku Alternatif Keramik Kasongan, Proceeding Annual Engineering Seminar 2012, Fakultas Teknik, UGM, Yogyakarta.

Wahyuni, N., Cita, dan Anita Z., T., 2012, Analisis Whiteness Kaolin Asal Mandor pada Variasi Temperatur Pemanasan,Jurnal Positron, Volume II, no 2 tahun 2012, Jurusan Kimia FMIPA Universitas Tanjungpura, Pontianak, hal. 15-20. 